\title{
BRASIL - ESTADO E NAÇÃO
}

\author{
Cristiane Derani \\ Professora Doutora do Departamento de Direito \\ Econômico-Financeiro da Faculdade de Direito da \\ Universidade de São Paulo
}

\begin{abstract}
Resumo
A formação brasileira é um processo de reprodução de antagonismos múltiplos e espalhados por todos os aspectos da vida social. Predominando sobre todo antagonismo, o mais sedimentado em nossa história é o antagonismo entre o senhor proprietário e o braço trabalhador da terra que não possui. A cultura se forma com a apropriação e modificação do ambiente. A formação das instituições é um processo cultural. No Brasil, com a predominância do personalismo no mando e nas ações políticas, o Estado e o Direito se formam mais como expressões pessoais do que como reflexões de vontades coletivas. O episódio da independência de fato cristaliza a idéia de povo brasileiro, pelo reconhecimento da Nação brasileira. A Constituição de 1824 demonstra o nascimento do Estado brasileiro. A sucessão de Constituições confirma o Estado brasileiro e modifica sua configuração, bem como representa novas posições assumidas pelo seu povo num renovar da Nação. Com maior ou menor permeabilidade às reivindicações sociais, o Estado encontra na Constituição sua forma. Conclui-se que a força da Nação sobre a formação do Estado brasileiro varia nos diversos momentos de nossa história.
\end{abstract}

\begin{abstract}
The formation of Brazil is a process that reproduces several antagonisms, spread over all the aspects of social life. The dominant antagonism, settled most heavily on our history, is the one between the landowner and the labourer, who works on a land he does not own. Culture is built through appropriation and modification of the environment. The identity of a people is translated into its cultural formation. The formation of institutions is a cultural process. In Brazil, where personal relationships predominate in commandments and in political actions, the State and the Law are built not so much as reflections of the collective will, but rather as personal expressions. The Constitution of 1824 highlights the birth of the Brazilian State. The long row of Constitution confirms the Brazilian State and modifies its configuration. It also represents new positions taken by the people in the renewal of the Nation. In History, we can find the relationship between the development of the State and of the Brazilian Nation. We conclude that the influence of the Nation on the formation of the Brazilian State varies in the diverse moments of our history.
\end{abstract}

Unitermos: Nação; Estado; processo de formação brasileiro; povo brasileiro; propriedade; exclusão social. 
"Esta terra, ..., de ponta a ponta, é tudo praia-palma, muito chã e muito formosa. [...] Águas são muitas; infindas. E em tal maneira é graciosa que, querendo-a aproveitar, dar-se-á nela tudo, por bem das águas que tem"

(Pero Vaz de Caminha, Carta que escreveu ao rei d. Manuel, de Portugal, com data de I"de maio de 1500)

"... o cenário do Novo Mundo parecia apresentar-se àqueles primeiros conquistadores ... animado pela expectativa de um plus ultra de maravilha, encantamento e bem-aventurança, sempre a inundá-lo em sua luz mágica. [...] De qualquer modo, os cenários naturais, em terra onde tudo era insólito, pareciam importar, não tanto por aquilo que aparentavam, mas sobretudo pelo que pareciam anunciar ou dissimular.

Entre a generalidade dos exploradores e povoadores portugueses, por outro lado, mal se pode dizer que, no Brasil, aquelas visões ou promessas miraculosas chegassem a assumir papel considerável em sua atividade colonial." (Sérgio Buarque de Holanda, Visão do Paraíso, editora Brasiliense, São Paulo, 1992, p. 243)

"O provável, no entanto, é que os motivos edenicos facilmente se refrangiam entre eles, privando-se da primeira intensidade para chegarem ao que se pode chamar sua atenuação plausivel. Não é talvez sem interesse o exame dessa circunstância e de tudo quanto dela resultou para o desenvolvimento da exploração e colonização do Brasil."(idem, p. 246)

Ibirapitanga é a madeira cobiçada pelos reis de Portugal, encontrada em terras ao sul do equador e que atrairá o reino europeu do século XVI. É na extração do fruto vermelho da terra que se estabelecerão as primeiras relações entre os continentes e entre seres humanos distintos em seu passado e presente, ligados no futuro por relações ambíguas de formação de uma história comum e agudos conflitos do homem contra o homem. Uma história que se inicia nos primeiros momentos da apropriação da terra. A mesma terra, objeto de expansão humana, não abriga a todos, mas é o centro do conflito de meio milênio.

A busca pelo fruto da terra não une os homens perante um objeto comum, mas os opõe. A terra buscada, elemento agregador dos homens em comunidade para produção de suas vidas, é o pomo do confronto enraizado neste agregado humano, descaminhado na luta dos homens contra os homens. As visões antagônicas da terra e dos seus frutos, os conflitos que destas decorrem, marcam o nascimento do Brasil nome europeu da madeira explorada - Nação e Estado.

A formação brasileira é um processo de reprodução de antagonismos múltiplos e espalhados por todos os aspectos da vida social. Predominando sobre todos 
antagonismos, o mais sedimentado em nossa história é o antagonismo entre o senhor proprietário e o braço trabalhador da terra que não possui.' Nossa identidade não se baseia em certezas raciais ou em orgulhos de linhagem. As raizes do Brasil não se encontram no solo da tradição. Estão fincadas no húmus da aventura, do transplante, do improviso. A formação do povo brasileiro é a formação das novas relações sociais que se estabelecem naquele solo americano do hemisfério sul demarcado por Portugal. Desgarrados de suas matrizes, cruzados racialmente e transfigurados culturalmente, os primeiros "brasileiros" são um emblema do novo e da busca de uma identidade. Contudo, esta busca não se desenvolve em comunidade, mas em posições conflituosas, polarizadas. Darcy Ribeiro nos ensina que é construida uma classe dominante de caráter consulargerencial, socialmente irresponsável, frente a um povo-massa tratado como escravaria, que produz o que não consome e só se exerce culturalmente como uma marginália, fora da civilização letrada em que está imersa ${ }^{2}$ Sérgio Buarque de Holanda aponta a tentativa de implantação da cultura européia em extenso território, dotado de condições naturais completamente distintas, como um fato que não vai passar sem profundas conseqüências. "Trazendo de paises distantes nossas formas de convivio, nossas instituições, nossas idéias, ..., somos ainda hoje uns desterrados em nossa terra" 3

De fato, o olhar brasileiro perante sua terra não se desprega da visão do outro mundo. A visão do Brasil, no seu retrato por aqueles que aqui aportam, é idealizada, desterrada; os olhos que miram a terra vêem a idéia, boa ou má. Se para os primeiros europeus que chegam ao Brasil, o relato era o do paraíso; para os colonizadores e senhores, olhar para o Brasil era a reprodução da nostalgia, a visão do não querer, a realidade da perda do bom e do ideal, que procuravam reproduzir em ilhas de sociabilidade destacadas das relações sociais e naturais que concretamente lhes eram oferecidas. O sonho europeu substitui um possível sonho americano nestas paragens, abrasando o conflito permanente no processo de formação do povo brasileiro. Darcy Ribeiro chega a afirmar que "vivemos praticamente em estado de guerra latente, que, por vezes, e com freqüência, se torna cruento, sangrento". 4

Não-obstante, não é raro ouvirmos - de brasileiros ou estrangeiros - que o Brasil é um país pacífico. "Não ambicionamos o prestígio de país conquistador e detestamos notoriamente as soluções violentas. Desejamos ser o povo mais brando eo mais comportado do mundo... Tudo isso são feições bem características do nosso aparelhamento politico, que se empenha em desarmar todas as expressões menos harmônicas de nossa sociedade, em negar toda espontaneidade nacional" s

I. Cf. Gilberto Freyrc. Casa Grande e Senzala. Josć Olympio, Rio de Janciro, p. 53.

2. Darcy Ribciro. O Povo Brasileiro: a formação e o senticlo do Brasil. Companhia das Letras, São Paulo, 1995, p.179.

3. Sćrgio Buarque de Holanda. Raizes do Brasil. Companhia das Letras, 26a. edição, São Paulo, p.31.

4. Darcy Ribciro. opus cit., p. 168.

5. Sćrgio Buarque de Holanda. opus cit., p. 178. 
Diversas foram as revoltas e embates provocados pelos antagonismos do povo brasileiro. Poucos foram aqueles que findaram por mudanças institucionais ou por reorientação na vida cotidiana e poslítica. As mudanças surgem mais por decisões pessoais ou personalizadas do que como evidente resultado da força rẹivindicadora de massas descontentes. A arma do descrédito, da desmobilização, da representação da história por aqueles que a escrevem a seu favor, são mais solventes do que qualquer vitória armada. E mesmo quando esta se coloca inevitável, como no episódio de Canudos $^{6}$ Não é pela apologia da vitória militar que se escreverá a história, mas pelo esquecimento e destruição do sítio de Canudos, que alguma vez pôde por azar representar a luta latente contínua de oprimidos e opressores expressa como tensão inter-racial, econômica, social, classista, política.

O Brasil-colônia foi ocupado por portugueses que recebiam parcelas de terra para exploração. Para estes primeiros ocupantes, Brasil era o nome de um patrimônio que faziam produzir e que defendiam contra invasões eles próprios ${ }^{7}$ Também organizavam a Justiça e a administração. Deveras, a terra do Brasil surge como uma justaposição de patrimônios auto-administrados em que a figura do proprietário era também a figura do governador.

Esta administração, no entanto, não deve ser confundida com a propriedade feudal, dentre vários motivos, sobretudo pelo destino da sua produção. A gerência autocrática de extensas propriedades de terra consistia em pôr braços, cérebros, terra para a satisfação do outro: o desconhecido, o estrangeiro, o inatingível, que entrava no processo produtivo para reter seu resultado, mas totalmente alheio ao processo que levou à produção. "Se vamos à essência de nossa formação, veremos que na realidade nos constituímos para fornecer açúcar, tabaco, alguns outros gêneros; mais tarde ouro e diamantes; depois algodão, e em seguida café, para o comércio europeu. Nada mais que isto. É com tal objetivo, objetivo exterior, voltado para fora do pais e sem atenção a considerações que não fossem aquele comércio, que se organizarão a sociedade e a economia brasileiras" 8

"O Brasil foi regido primeiro como uma feitoria escravista, exoticamente tropical, habitada por indios nativos e negros importados. Depois, como um consulado, em que um povo sublusitano, mestiçado de sangues afros e indios, vivia o destino de um proletariado externo dentro de uma possessão estrangeira. Os interesses e as aspirações do seu povo jamais foram levados em conta, porque só se tinha atenção e zelo no atendimento dos requisitos de prosperidade da feitoria exportadora. O que se estimulava era o aliciamento de mais indios trazidos dos matos ou a importação de mais negros trazidos da África, para aumentar a força de trabalho, que era a fonte de produção dos lucros da metrópole. Nunca houve aqui um conceito de povo, englobando

6. Conflito cntre uma comunidade no scrtào da Bahia c o Estado Brasilciro em 1896.

7. Rodolfo Garcia. Ensaio sobre a História Administrativa do Brasil. Livraria José Olympio, Rio de Janciro, $2^{a}$ cd., 1975, p. 21.

8. Caio Prado Jr. História Econômica do Brasil. Brasiliensc, 23 cd., São Paulo, 1980, p. 23. 
todos os trabalhadores e atribuindo-lhes direitos. Nem mesmo o direito elementar de trabalhar para nutrir-se, vestir-se e morar.

Essa primazia do lucro sobre a necessidade gera um sistema econômico acionado por um ritmo acelerado de produção do que o mercado externo dela exigia, com base numa força de trabalho afundada no atraso, famélica, porque nenhuma atenção se dava à produção e reprodução das suas condições de existência"'

Durante os três primeiros séculos de existência, o Brasil não tinha qualquer traço de formação de um Estado. A distribuição de territórios para proprietários portugueses com poderes absolutos sobre a terra e sobre a gente, cuja única obrigação era para com o Rei de Portugal, remetendo-lhe as riquezas que ingressavam na roda mercantilista do mercado europeu, impedia qualquer germe de organização política. Contudo, este processo de recrutamento de pessoas de quem se retirava o passado e o futuro - escravos negros, índios aprisionados, e criminosos brancos de Portugal -, que jamais pretendeu originar um povo autônomo, foge do domínio do planejamento colonial. Neste transplante de gentes, é inegável a existência de uma certa força natural catalisadora das gentes que impede a existência do ser humano mônada. O Brasil recebia gentes no extremo da expropriação material, cultural, familiar. Deserdados, não se limitavam à vida autômata servil e iniciavam uma cultura diversa, com base em reminiscências e na adaptação ao novo cotidiano. Escravos, degredados, indios cativos, e de certo modo, mesmo o branco português desterrado, faziam surgir uma nova entidade étnica, uma nova configuração cultural, um novo povo, de índios destribalizados, negros desafricanizados, brancos deseuropeizados, mas que, apesar de todos os conflitos que mantinham entre si, trocavam culturas abandonadas. Com todos os preconceitos e hierarquias, deixavam-se permeabilizar, absorvendo o outro num processo canibal, da fome de cultura e de identidade que se perpetuará na vida do povo brasileiro que explodia.

O povo brasileiro até o século XIX se formava com estes três elementos. O Brasil era uma região fechada à imigração. A entrada de pessoas no Brasil era regulada e a lei permitia a vinda apenas de portugueses degredados, proprietários agraciados pela coroa e aqueles que provavam trazer interesse econômico. Afora isto, só entravam escravos. Era a forma de preservar o poder ultramarino.

A atividade econômica do Brasil-colônia era fortemente regulada e toda atividade liberal firmemente proibida ou altamente taxada, impossibilitando outro desenvolvimento senão o de servil abastecimento da corte com matérias-primas necessárias a ela e ao seu comércio com a Europa.

A liberdade de comércio era sumariamente tolhida, do mesmo modo que o exercício de certas indústrias, que ora desaparecia a beneficio de outras, ora era limitado a certas regiões ou circunscrições, ou ainda a determinado número de indivíduos incorporados ou não em companhias ou sociedades. Desse modo foi que a coroa tentou

9. Darcy Ribciro. opus cit., p.441. 
por vezes o sistema de estancos de certos gêneros, como foi desde o princípio o paubrasil. $^{10}$

Em 1808, com as Guerras Napoleônicas, a família real portuguesa instalase no Brasil e encerra o período de exploração colonial pura. Ainda sob forte restrição quanto à imigração e às formas de produção, abre-se um pouco o comércio e permitese a manufatura de alguns determinados gêneros básicos. É o germe do Estado que está sendo aquecido. Em 07 de setembro de 1822, o primogênito do Rei de Portugal proclama a Independência, que se faz sem grandes alardes, com o rebentar de algumas revoltas entre portugueses - recém-chegados ao Brasil - e aqueles que se denominavam brasileiros - habitantes da terra. Embora representem uma forte reorientação política, as agitações liberais que antecederam a independência foram promovidas por algumas famílias ricas e poderosas. A massa do povo, identificava Saint-Hilaire, "ficou indiferente a tudo, parecendo perguntar como o burro da fábula. Não terei a vida toda de carregar a albarda?" "I.

O episódio da Independência de fato cristaliza a idéia de povo brasileiro, pelo reconhecimento da Nação brasileira. Este momento de desprendimento político marcará definitivamente a existência de um novo povo e de uma nova Nação na face da Terra. A força desta identidade não é nada desprezível, quando se remarca que, apesar do pipocar de conflitos entre portugueses e brasileiros, e mesmo alguns com cunho republicano, o território brasileiro conservou sua amplidão, e a língua, pilar da formação da identidade dos brasileiros de pouca tradição, manteve-se mesmo nos mais inacessíveis vilarejos e pequenos aglomerados humanos do território brasileiro.

Com a Independência, inicia-se a formação da burocracia brasileira. Imbuído das idéias liberais, o imperador Pedro I procura fazer do país uma monarquia parlamentar. Contudo, desde o seu nascedouro, a ideologia impessoal do liberalismo democrático "foi sempre um lamentável mal-entendido" 12 . A aristocracia rural tratou de acomodá-la, onde fosse possível, aos seus direitos ou privilégios. Não-obstante, sem poucas divergências entre imperador e parlamentares, o Brasil Império recebe a sua primeira Constituição em 25 de março de 1824.

A cristalização jurídica do Estado e da Nação brasileira estarão presentes nos primeiros artigos dessa Carta:

“Art.l. O Imperio do Brazil é a associação Política de todos os Cidadãos Brazileiros. Elles formam uma Nação livre, e independente, que não admite com qualquer outra laço algum de união, ou federação, que se oponha a sua Independência.

10. Rodolfo Garcia. opus cit., p. 115.

11. Sćrgio Buarque de Holanda. opus cit., p.161.

12. idem, p. 160. 
Art. 6. São Cidadãos Brazileiros:

I - Os que no Brazil tiverem nascido, quer sejam ingenuos, ou libertos, ainda que o pai seja estrangeiro, uma vez que este não resida por serviço de sua Nação.

II - Os filhos de pai Brazileiro, e os ilegitimos de mãe Brazileira, nascidos em paiz estrangeiro, que vierem estabelecer domicilio no Império.

III Os filhos de pai Brazileiro, que estivesse em paiz estrangeiro em serviço do Imperio, embora elles não venham estabelecer domicilio no Brazil.

IV Todos os nascidos em Portugal, e suas Possessões, que sendo já residentes no Brazil, na época, em que se proclamou a Independencia nas Provincias, onde habitavam, adheriram à esta expressa, ou tacitamente pela continuação da sua residência.

\section{$V$ - Os estrangeiros naturalizados, qualquer que seja a sua religião."}

Embora a organização política brasileira se modificasse de modo essencial - o Estado brasileiro se formava -, o movimento de produção econômica, o emprego de recursos e os produtos obtidos mantinham a mesma dinâmica da época colonial. Aqueles senhores da terra, das gentes, do poder político-econômico e administrativo, deixam seus domínios agrários e vão compor a burocracia do Estado nascente. Evidentemente que se vai obter a mais perfeita confusão da vida pública e da vida privada. Conforme afirma Buarque de Holanda: "Não era fácil aos detentores das posições públicas de responsabilidade,..., compreenderem a distinção fundamental entre os domínios do privado e do público. ... a própria gestão política apresenta-se como assunto de seu interesse particular; as funções, os empregos e os beneficios que deles aufere relacionam-se a direitos pessoais do funcionário e não a interesses objetivos, como sucede no verdadeiro Estado burocrático, em que prevalecem a especialização das funções e o esforço para se assegurarem garantias juridicas aos cidadãos. "13

Com estas características, o Estado não era pensado como um aparelho despersonificado, uma entidade coletiva. O Estado é visto e usado como 'propriedade' do grupo que o controla. Era um reajustamento das capitanias hereditárias, e da mesma forma que a aristocracia exercia seu poder de mando em suas extensões dominiais, passou a exercê-lo sob a forma de Estado. O exercício do poder pessoal é burocratizado. Não há fins do Estado, mas a vontade do Imperador e a vontade da aristocracia, que se chocarão e darão origem a várias revoltas durante o século XIX.

Deve-se remarcar o efeito da produção maciça dirigida para o Exterior, inclusive na formação do aparelho burocrático. De fato, quando a administração sai da casa-grande do senhor-proprietário e passa à agência pública, faz-se necessária a formação dos cofres públicos, pela instauração do Estado Fiscal. A pobreza crônica em

13. idem, p. 146. 
que viviam os pequenos logradouros urbanos, e a ausência de atividade econômica que pudesse ser tributada e fortalecer os cofres públicos, freou a mudança política pretendida, e os cofres públicos, legados ao descaso e ignorados como fonte de renda para melhoria da vida pública, são apropriados e confundem-se com os bolsos particulares.

A atividade política era vista pelo homem simples como um luxo, diletantismo da aristocracia, como seus saraus e cigarros. Saint-Hilaire conta-nos: "Perguntei a um lavrador que não me parecia dos mais pobres, se os povos estavam contentes com o novo governo da capitania. - Dizem que é melhor que o antigo, respondeu-me. $O$ que há de certo é que quando se apresenta alguma petição, não se obtém resposta tão rápida quanto quando nosso general tudo por si decidia e isto é muito desagradável para os que não têm tempo a perder"14

Ao final do século XIX, o Poder Imperial está enfraquecido perante o ganho de força da aristocracia, agora travestida como aristocracia cafeeira, a qual concentrará grande parte da riqueza que ingressa no país. Deste embate entre casa real e aristocracia cafeeira, sobrevém a República, em 15 de novembro de 1889.

A proclamação da República foi um susto retratado na célebre carta de Aristides Lobo sobre 0-15 de novembro. Dizia o mentor da República infante: "por ora a cor do governo é puramente militar e deverá ser assim. O fato foi deles, deles só, porque a colaboração do elemento civil foi quase nula. O povo assistiu àquilo bestializado, atônito, surpreso, sem conhecer o que significava."

A vida social permanecia distante da vida política. O alheamento do povo da vida pública perdurou durante todo Império, recrudescendo na Proclamação da República. Alberto Torres denunciava à época o máximo de distância entre público e privado. "A força de alheação da realidade política chegou ao cúmulo do absurdo, constituindo em meio de nossa nacionalidade nova, onde todos os elementos se propunham a impulsionar e fomentar um surto social robusto e progressivo, uma classe artificial, verdadeira superfetação, ingênua e francamente estranha a todos os interesses, onde, quase sempre com a maior boa-fé, o brilho das fórmulas e o calor das imagens não passam de pretextos para as lutas de conquistas e a conservação das posições" 16

Na Proclamação da República, o Partido Republicano existia em São Paulo, em Minas Gerais, no Rio Grande do Sul e no Rio de Janeiro. Nos outros Estados, existiam patrulhas republicanas. Os dois partidos monarquistas - o liberal e o conservador -, diante da situação criada, dissolveram-se; e os seus componentes e chefes, com raras exceções, aderiram ao Partido Republicano, que então tomou corpo e se instalou nos governos de todos os Estados.

14. Maria Sylvia de Carvalho Franco. Homens Lives na Ordem Escravocrata. Kairós, 3" ed., São Paulo, 1983, p.83.

15. Buarque de Holanda. opus cit., p. 161.

16. idem, p. 178. 
Neste alheamento surge a primeira Constituição republicana em 1891, sobre a qual Alberto Torres não poupará as suas severas críticas: "Fruto de uma revolta sem cultivo prévio na opinião, e sem preparo organizador, surgida, inesperadamente das trevas da conspiração política, para a realidade, por força de um trabalho subterrâneo, favorecido por alguns acidentes da politica imperial: a abolição dos escravos e a moléstia do monarca, principalmente prenunciando, este último, a aproximação do terceiro reinado, antipático, em geral, ao sentimento popular - a lei máxima da república não é senão uma roupagem de empréstimo, vestindo instituições primitivas" 17

Este descontentamento e amargor denuncia o desejo de ver o pais finalmente se transformar numa Nação identificada internamente e condutora dos rumos do Estado. Segue Alberto Torres:18

"No Brasil (...) Estado e sociedade hão de organizar-se reciprocamente, por um processo mútuo de formação e de educação. Educação pela consciência e pelo exercicio, a que vale dizer por um programa, isto é, por uma política: eis o meio de transubstanciar este gigante desagregado em uma nacionalidade."

"O Brasil tem estado, até hoje, ao serviço das formas de governo e das doutrinas que tem adotado: cumpre que a República passe, por sua vez, a servi-lo."'19

E continua, denunciando o aparelho governamental: "Não é licito duvidar de que toda atividade de nossa vida pública está absorvida pelo enredo a que chamamos politica, nessas sucessões de lutas pessoais e de grupos, guerras de campanário ... todo um mecanismo parasita ... não passa de uma vegetação de caudilhagem e destruição ... . A oligarquia democrática explora a vida pública no Brasil com o mesmo desembaraço que os senhores punham em explorar seus vassalos". ${ }^{20}$

"Não é verdadeira a nacionalidade de um pais que não tem a sua política, e não há verdadeira política que não resulte do estudo racional dos dados concretos da terra e da sociedade, objeto e verificado na experiência" 21

É impossível esconder o jorro de esperança que a Proclamação da República, mesmo que sem a participação do povo, trouxe à formação do Brasil. Este ato militar, aristocrático, que seja. De interesse econômico, político-hegemônico, traz, involuntariamente, a certeza de que a identidade brasileira não era comensal da vida portuguesa, e que os seres humanos responsáveis pela formação do Brasil não eram coisas, porque não eram mais escravos, nem bandidos, porque não eram mais degredados, nem inseridos pela força numa nova Nação, porque não eram mais índios cativos.

A abolição dos escravos em 1888, traz ato-contínuo a liberdade da imigração. Liberdade de indústria, que não se submetia às restrições ainda presentes

17. Albcrto Torres. A Constituição de 1891, Companhia Editora Nacional, São Paulo, 1978, p.34.

18. idem, p.37.

19. idem, p.58.

20. idem, p. 173

21. idem, p. 151. 
no Império, e mesmo a criação do Banco de Crédito popular para estimular os empreendimentos privados, em 14 de novembro de 1890. Sem dúvida, o século XX marca uma nova formação do Brasil. Este século ficará marcado pela não aceitação do distanciamento da vida pública da vida privada nem da promiscuidade dos fins e receitas públicos com os interesses particulares da autoridade que os manipula.

Embora o ideal republicano permeasse mais profundamente a sociedade brasileira no final do século XIX, a República foi conquista aristocrática, que, a espelho de tudo que consumia, importou os ideais, a forma e a Constituição, surgindo uma República no nome, que nada tinha de "coisa" do "povo" - nem patrimonialmente, nem no seu ideário.

Nos moldes dos EUA, é escolhido o sistema federativo. No entanto, os Estados da Federação não tinham a prática autônoma, pois o Brasil saía do poder monárquico centralizado. E, na expressão de Oliveira Torres: "Sem dinheiro não há Federação"22

Em essência, é possível dizer que a Constituição republicana cristalizava o movimento que a fez nascer - como é o caso de toda Constituição. Ocorre que este movimento republicano era o movimento da oligarquia do café, que estendeu sua influência sobre os demais Estados da Federação pela conquista política e pela determinação das normas Constitucionais que irão perdurar até 1930. Serão quase quarenta anos de consagração jurídica e política do sistema agrário monocultor, baseado na lavoura do café, pouco dado a planos industrialistas e creditícios, muito menos ligado a qualquer pequena idéia de democratização. É ainda esta primeira Constituição republicana que vai cassar o direito outorgado pelo art. 179 da Constituição do Império de que "a instrução primeira é gratuita a todos os cidadãos". Este recuo vai perdurar até 1934, quando as correntes da mudança social lograrão ponderáveis triunfos em sua influência sobre o constitucionalismo pátrio. ${ }^{23}$

Em 1930, aproveitando a crise mundial de 1929 que enfraqueceu e mesmo destruiu parte da oligarquia cafeeira, estoura a revolução que leva a vitória ao candidato gaúcho, estrangeiro à mesa do café de São Paulo. Getúlio Vargas assume a presidência pelo "prélio das armas", sob a promessa de dar ao Brasil uma nova Constituição, e ficará ditador por quinze anos no poder.

Dois anos depois adveio a oligarquia cafeeira de São Paulo, aliada aos ideais liberais e constitucionalistas, promove uma revolução, buscando retomar o poder, agitando o estandarte da Constituição prometida mas não cumprida. A Revolução de 32 é reprimida e em 1934 é outorgada uma nova Constituição ao Pais, que viverá três anos no governo personalista de Getúlio.

A Constituição de 1934 é a consagração dos direitos sociais. Inspirada pela Constituição de Weimar, define o papel do Estado no desenvolvimento econômico

22. Heitor Ferrcira Lima. História-Politico-econômica e Industrial do Brasil, 2" Ed. Ed. Nacional, São Paulo, 1976, p. 295

23. Paulo Bonavides. "O princípio idcológico nas Constituiçõcs Brasilciras", in Reflexões Politica e Direito. Malhciros, São Paulo, 1998, p. 291. 
e social. Trará um capítulo intitulado "Da ordem econômica". que procurará organizar a atuação do Estado no domínio econômico "conforme os princípios da justiça e as necessidades da vida nacional, de modo que possibilite a todos existência condigna"

Ao contrário das primeiras décadas da República, o ideal do desenvolvimento industrial do país se faz manifesto, seja pela previsão de nova regulamentação do crédito mais favorável para o investimento, seja definindo a instituição de monopólios estatais que alavancariam o parque industrial.

A preocupação com a pobreza e o analfabetismo, bem como com a saúde e a assistência social, ingressam pela primeira vez no campo da organização do Estado, pois se tornam matérias constitucionais. E o Brasil consagra a forma de constituição material em oposição à constituição formal. A partir de 1934, as Constituições brasileiras organizarão o Estado pelo seu aspecto administrativo-burocrático, e também pelo seu conteúdo político-ideológico, definindo as suas finalidades, os porquês de sua existência.

Disposições sobre o amparo à maternidade e à infância, socorro a famílias de prole numerosa, salário-mínimo (art. 138), são alguns dos deveres constitucionais do Estado que o vincula com a Nação, fazendo das Constituições brasileiras Carta de Direitos do povo brasileiro, e não construção formal da ordem estatal.

A Constituição de 1934 protege o direito de propriedade e vincula seu exercicio ao interesse social ou coletivo. Proibe foros privilegiados e tribunais de exceção. Recoloca com maior riqueza o dever do Estado em prestar a educação: "A educação é direito de todos e deve ser ministrada pela familia e pelos poderes públicos, cumprindo a estes proporcioná-la a brasileiros e a estrangeiros domiciliados no pais, de modo que possibilite efficientes factores da vida moral e econômica da Nação, e desenvolva num espírito brasileiro a consciência da solidariedade humana" (art. 149)

Basta este artigo para se obter um fiel retrato do transbordar de sonhos e ideais de um país que se julgava finalmente 'burguês', finalmente aparelhado dos ideais liberais, e liberto do comando oligárquico que agrilhoava em elos de subordinação, exploração e opressão a recém-nascida Nação brasileira. Do vínculo estabelecido pela força, pela necessidade ou mesmo pela miséria que anula toda opção, procura-se, na forma de texto de Constituição, fazer da sociedade brasileira uma rede estabelecida pela vontade e fechada em laços de solidariedade.

A Constituição, mandamentos cristalizados, expõe em verbo o que já aflorava na sociedade: a busca acumulada em séculos do reconhecimento da identidade brasileira pelo reconhecimento da existência de um povo-cidadão, portador de voz e proprietário de direitos; sujeitos construtores do país; não o objeto, solo, mato e foice, com que o confundia o senhor de engenho do passado ainda quente. ${ }^{24}$

24. "A cidadania é a prova de identidade que mostra a relação ou vinculo do individluo com o Estado. É mediante essia relação que uma pessoa constitui fração ou parte de um povo. (...) Sendo a cidadania um circulo de capacidade conferido pelo Estado aos cidadãos, este poderá traçar-lhe limites. (...) De qualquer maneira é um status que define o vinculo nacional da pessoa, os seris direito e deveres em presença do Estaclo e que normalmente acompanha cada individuio por todla a vida. ". Paulo Bonavides. Ciência Politica, Malhciros, 1997, p. 77. 
Contudo, a dose de ideal inoculada na Constituição foi forte demais perante as forças politicas menos "socializantes" do que os mandamentos constitucionais. A Constituição revolucionária de 1934 pereceu na contra-revolução de 1937. Getúlio Vargas substitui a Constituição por una própria e permanecerá no poder por um golpe de Estado até 1945.

Nesse periodo ditatorial, conhecido como 'Estado Novo', foram muitas as modificações econômicas e sociais do país. Sem democracia, sem liberdade política, este Estado autocrático, de censura e perseguição e mesmo de tortura dos militantes comunistas - aumentou em $60 \%$ o nível de escolarização básica, impulsionou a indústria, criou monopólios nacionais e fez o Estado assumir a produção da indústria de base, estabelecer a primeira legislação trabalhista do país - ao molde da Carta del Lavoro, de Mussolini. A greve e o lock-out foram proibidos e os sindicatos foram atrelados ao governo.

Em 1943, os estudantes universitários começam a se mobilizar contra a ditadura. No mês de dezembro, em São Paulo, os acadêmicos da Faculdade de Direito e demais universitários realizam uma passeata, caminhando de braços dados e com um lenço na boca, simbolizando a supressão da palavra. A manifestação é dişsolvida violentamente pela Polícia, provocando uma onda de indignação.

Movido pela crescente insatisfação popular e pelo aumento das pressões políticas, Getúlio Vargas convoca eleições. Tem seu candidato eleito, general Dutra, o qual convoca imediatamente eleições para Assembléia Constituinte. Apesar da longa ditadura, Getúlio candidata-se ao legislativo e com maciço apoio se torna senador da República. A nova Constituição é promulgada a 18 de setembro de 1946.

A diretriz social combinada com o Estado atuante permanece na Constituição de 1946. De fato, a formação da Constituinte de 1946 foi a mais diversificada que o Brasil já havia experimentado. A classe média fortalecida e identificada, e o início de um movimento operário organizado que, mesmo perseguido durante o Estado Novo, foi capaz de aglutinar o operariado urbano já bastante numeroso, levou pelo voto direto representantes de matizes políticos vários, que escreveram mais esta Constituição que orientará a vida do país no período de maior crescimento econômico de sua história (1946-1967). A disposição dos constituintes era de buscar a conciliação, um compromisso por uma trégua institucional.

O Texto de 1946 mantém a declaração de que a ordem econômica deve estar consoante com a Justiça social. Os princípios de trabalho que asseguram existência digna, assim como o reconhecimento do trabalho como um direito, são inovações deste período pós-guerra e pós-ditadura.

Evidentemente, não foi este o único fator, mas de fato a sociedade brasileira pós-46 passou a construir sua identidade a partir de objetivos públicos comuns - algo inédito em nossa história. A eleição da constituinte de 46 foi um dos sintomas de consciência de todo. A luta pela nacionalização do petróleo encheu todas as bocas: "o petróleo é nosso". As empresas prestadoras de serviços públicos foram nacionalizadas, também os frigoríficos e as indústrias farmacêuticas. A remessa de lucros para o exterior 
sofreu pesada regulamentação. Problemas como o anal fabetismo e o latifúndio passaram a ser temas correntes da intelectualidade urbana. Em 1952, nasce o Banco Nacional de Desenvolvimento, destinado a mobilizar recursos para incentivar as atividades de infraestrutura: transportes, energia elétrica e indústrias de base.

O rápido crescimento da produção industrial, contudo, não diminuiu os problemas do campo, ainda fincado na estrutura colonial, latifundiária, monocultora, voltada ao abastecimento externo. Surgiram as ligas camponesas que propunham entre outras coisas defender os camponeses contra a expulsão da terra e a elevação do preço dos arrendamentos. Denunciado fortemente por Caio Prado Jr., o sistema agrário, ainda próximo ao escravista, deveria ser reformulado por uma legislação que regularizasse as relações de produção capitalistas e que garantisse a superação de uma ordem social heterogênea. Caio Prado Jr. busca no nível legal, de ordem jurídica e institucional, levar as propostas de uma revolução burguesa que atribuiria a cidadania ao trabalhador rural definida pelo contrato, pelos princípios da liberdade, igualdade e propriedade. Reclama o equilíbrio básico nas relações no campo, incluindo os direitos à sindicalização, à greve, à habitação conveniente e à regulamentação do salário, permitindo à "massa trabalhadora do campo ... sair da marginalidade em que se encontra e integrar-se na vida geral do país" Isto é, ações que contribuíssem para a constituição de uma 'coletividade nacionalmente integrada e organizada', que impulsionassem o desenvolvimento do mercado interno, especialmente o mercado de trabalho. ${ }^{25}$

Um avanço legislativo se deu em março de 1963, quando o então presidente João Goulart sancionou uma lei que dispunha sobre o Estatuto do Trabalhador Rural. A lei instituiu a carteira profissional para o trabalhador do campo, regulou a duração do trabalho e a observância do salário mínimo e previu direitos como o repouso semanal e as férias remuneradas.

Em 31 de março de 1964, as forças armadas tomam o poder. Uma junta militar expulsa o presidente da república, e iniciam-se as perseguições políticas, inicialmente contra a União Nacional dos Estudantes - UNE, as Ligas Camponesas e os sindicatos. Ainda, quarenta e nove juízes foram imediatamente expurgados e cinqüenta parlamentares tiveram o mandato cassado no mesmo ano. A Constituição foi suspensa e uma série de atos de emergência, chamados Atos Institucionais, sucederam-na. O primeiro estabelece a eleição indireta para presidente, que passa a ser por voto público dos deputados. O Congresso é fechado e reconvocado para chancelar formalmente o novo texto constitucional de 1967.

A ditadura atinge seu ápice em 1968, com o fechamento definitivo do Congresso, e um novo ciclo de cassação de mandatos, perda de direitos políticos e expurgos no funcionalismo, abrangendo muitos professores universitários. No lugar da Constituição, atos do poder executivo perfazem a Lei Maior, são os Atos Institucionais

25. Maria Isabcl Leme Falciros. "Uma visita Nccessária”, in História e ideal: ensaios sobre Caio Prado Jr:, Brasilicnsc, São Paulo, 1989. p. 148. 
- AI. Estabelece-se na prática a censura aos meios de comunicação, a tortura passa a integrar os métodos do Governo.

O terror espalhado, a desmobilização política alcançada, vão repercutir até hoje no país que ainda não foi capaz de reconstruir a consciência de povo e o sentimento de nacionalidade que se aprofundava nos anos cinqüienta e sessenta.

O Estado de Direito sofreu o seu maior golpe. A ditadura militar suplantou aquela dos anos trinta de Getúlio em censura e violência. A Constituição de 1967 era mera formalidade em sua carta de direitos, que os prescrevia em um artigo e criava as exceções a seu exercício nos artigos seguintes. Em 1969, por uma emenda, surge a Constituição de 1969, sem qualquer participação do Congresso. Apesar de fortemente esmagada, a oposição se fazia, seja fora do país, por aqueles que estavam no exílio, seja pela dolorosa reorganização de um operariado que redescobria o sindicalismo e aliava a luta por direitos econômicos aos direitos políticos.

Após a lei de anistia, em 1985, realizam-se as primeiras eleições diretas para presidente, já com o pluripartidarismo restabelecido. Na mesma época, há eleições para deputados-constituintes encarregados de elaborar nova carta constitucional.

Em 1988, nasce a atual Constituição. Após vinte anos de violenta repressão política e civil, que jogou o povo no alheamento da vida pública e econômica do país, a Carta de 1988 procura restabelecer pela palavra o Estado de Direito que não mais vivia. Um congresso pluripartidário não foi competente para afastar da maioria os parlamentares da ditadura. Acompanhado pela oposição convalescente, não obstante, construíram um texto que ficou conhecido como "Constituição Cidadã"

Apesar de criticada pela sua extensão e por certa impropriedade de técnica constitucional no tratamento de minúcias - não de pouca importância -, a Constituição de 1988 é o discurso do sonho brasileiro. O poder deve ser exercido pelo povo - ele mesmo - assim como por seus representantes (art. $1^{\circ}$, parágrafo único). A construção de uma sociedade livre, justa e solidária, o desenvolvimento nacional, a erradicação da pobreza e redução de desigualdades sociais e regionais, o bem de todos sem qualquer forma de discriminação são os objetivos fundamentais da República Brasileira (art. $3^{\circ}$ ). A extensa declaração de direitos, que reforça as garantias individuais, institui novos remédios processuais para defesa do cidadão e a gratuidade das ações de habeas corpus e habeas data. A ressaca do passado violento recente traz neste artigo a declaração de que "constitui crime inafiançável e imprescritivel a ação de grupos armados, civis ou militares, contra a ordem constitucional e o Estado Democrático" (art. 5, XLIV).

É ressuscitada na forma de norma constitucional a questão da propriedade agrária, em vários pontos do texto, iniciando no art. $5^{\circ}$, que dispõe sobre os direitos e deveres individuais e coletivos: a propriedade atenderá a sua função social (XXIII); a pequena propriedade rural, assim definida em lei, desde que trabalhada pela familia, não será objeto de penhora para pagamento de débitos decorrentes de sua atividade produtiva, dispondo a lei sobre os meios de financiar o seu desenvolvimento. (XXVI).

A este artigo segue uma extensa carta de "direitos sociais", que discorre sobre os direitos dos trabalhadores urbanos e rurais. Princípios próprios de legislação 
trabalhista alçam o status constitucional, alimentado pela idéia de que o que está inscrito na Constituição impregnará mais certo e profundamente a vida social. A criação do seguro-desemprego (art. $7^{\circ}$, II), do fundo de garantia por tempo de serviço (III), participação nos lucros ou resultados da empresa (XI), proteção do mercado de trabalho da mulher (XX), o dever de assistência gratuita aos filhos e dependentes desde o nascimento até seis anos de idade em creches e pré-escolas (XXV), proteção em face da automação (XXVII).

Extensos são os artigos da "Ordem Econômica" e da "Ordem Social" Tudo precisava ser abordado, definido, defendido e imposto, pelo poder da palavra. $O$ ideário, o mando e a retórica se misturavam e fundiam, para não serem mais identificados isoladamente.

De modo algum cabe a crítica de que a Constituição de 1988 estava alheia à sociedade brasileira. Como toda Constituição, ela é uma percepção da sociedade, de uma parte de suas manifestações expressas ou latentes, mas indubitavelmente existentes. E ainda ela revela mais que aspectos da sociedade atordoada, que volta a sua casa de onde foi expulsa, ocupada e alterada sem sua permissão. A Constituição Cidadã é o maior exemplo de certa crença inscrita na formação cultural brasileira de que leis constituem o único requisito obrigatório da boa ordem social. Como nos ensina a sensibilidade de Sérgio Buarque de Holanda: "Escapa-nos esta verdade de que não são as leis escritas, fabricadas pelos jurisconsultos, as mais legítimas garantias de felicidade para os povos e de estabilidade para as nações"26 Reformas verdadeiras exigem que "por trás do edificio do Estado, existam pessoas de carne e osso. As constituições feitas para não serem cumpridas, as leis existentes para serem violadas, tudo em proveito de individuos e oligarquias, são fenômeno corrente em toda a história da América do Sul. É em vão que os politicos imaginam interessar-se mais pelos principios do que pelos homens: seus próprios atos representam o desmentido flagrante dessa pretensão" 27

É inegável que o texto constitucional estimulou práticas significativas de cidadania. O fortalecimento do Ministério Público, no seu papel civil de representar os interesses da sociedade no Judiciário, para moradia, educação, proteção do meio ambiente, do consumidor, do patrimônio histórico, constitui um avanço e uma arma no esforço de se diminuir a distância entre o povo e as instituições que historicamente o aterrorizam. Por outro lado, esta Constituição nem bem foi promulgada começou a receber pesadas críticas dos governantes do país, todos, que se sucederam nesta última década. Este criticismo foi acompanhado de atos deliberados do Poder Executivo que frontalmente a ofendiam. Parte destes atos receberam a recusa e a indignação da sociedade, que vai pleitear direito próprio ou coletivo, por meio do Ministério Público e associações civis, atulhando o Judiciário, que jamais havia se defrontado com tantos processos contra atos da União, dos Estados e Municípios.

26. Buarque de Holanda. opus cit., p. 178.

27. idem, p. 182. 
As leis, como as instituições de um povo, são dinâmicas, como dinâmicas são as relações humanas. Quanto menos sedimentadas as relações, quanto mais plurais forem os caminhos de um povo, maior será a dinâmica de suas instituições e maiores serão as modificações de seu estatuto normativo.

Estamos na trigésima-quinta emenda à Constituição. Ainda escutamos o discurso de ser este livro máximo de direitos o responsável pelos problemas do país. É certo que os grandes ideais de Justiça e igualdade escritos na Constituição não correspondem efetivamente às relações de poder que se passam de fato na sociedade brasileira, longe da equidade democrática. "Transformer effectivement dans le pays les rapports de fait des forces, entamer le pouvoir exécutif, y pénétrer de telle façon et transformer tellement qu'il ne pût plus jamais, par lui-même, s'opposer à la volonté de la Nation, - c'était cela qu'il fallait faire alors, et ce qui devait tout précéder, afin qu'une Constitution écrite pût être durable"'28 - já afirmava Lassale. A construção da cidadania necessita de princípios gerais fortes e impositivos.

"Povo sem nome das terras aradas

Tu vais morrer na poeira das estradas

Mas uma voz te mandará do espaço

A lei maior te fataliza o braço

Muitas vezes a gente se revolta

Não que falte a paciência de lutar

Muitas vezes a gente se revolta

Por incapaz de não se revoltar"

(Coral do Abandono, in O Café, Mario de Andrade)

"Canudos não se rendeu. Exemplo único em toda a história, resistiu até ao esgotamento completo. Expugnado palmo a palmo, na precisão integral do termo, caiu no dia 5, ao entardecer, quando cairam os seus últimos defensores, que todos morreram. Eram quatro apenas: um velho, dois homens feitos e uma criança, na frente dos quais rugiam raivosamente cinco mil soldados"

(Os sertões - Campanha de Canudos, Euclides da Cunha)

Sem dúvida, "a arma da crítica não pode substituir a critica das $\operatorname{armas}^{\prime 29}$ É fundamental no Brasil um texto tão minucioso, que traça o desejo da sociedade ideal, neste solo em que há quinhentos anos a prosperidade da alguns é adubada pelo suor de muitos. Entretanto, esta crítica deve interiorizar-se na consciência de todos. O povo brasileiro não passa ileso por quinhentos anos de construção de uma sociedade fortemente hierarquizada, que reduzia o que seria uma entidade cívica e

28. Fordinand Lassalle. Qu'Est-ce qu'une constitution?, Editions Sulliver, Arles, 1999, p. 56.

29. Karl Marx - Contribuição à Critica da Filosofia do Dircito de Hcgel, in Manuscritos cconômicosfilosóficos, (77-96), edições 70, Lisboa,1989,p.86. 
política a uma oferta de mão-de-obra servil. Somos herdeiros do modo de pensar autoritário, da valoração da cultura e dos interesses de uma esfera que insistia em se desenvolver de costas para os demais. O poder das palavras da Constituição revelarse-á efetivo quando efetivamente seus pensamentos forem apropriados pelos seres humanos senhores de seus destinos, transformando o verbo em ação.

A Nação brasileira não se constitui na passividade do fluxo regular de um rio, cujo destino é conhecido. Inúmeras foram as revoltas e insatisfações, algumas mesmo ameaçadoras à estabilidade do poder em exercício. Não cabe nesta conclusão desfiarmos os nomes e as vidas que se envolveram em busca de mudanças e, se sua vitória pode ser contestável, sem dúvida, seus atos fazem parte da liga que sela o Brasil como Nação. Se não é verdade a afirmação de que o brasileiro é um povo pacífico acostumado com autoridade e exploração, menos verdadeira ainda é a afirmação de que nossa história é coroada pela derrota de lutas que deixaram intactas as relações sociais. A formação de uma Nação se dá pelo modo como as relações são constituídas, relações estas cuja complexidade extrapola a percepção chã imediata da luta pelas coisas brutas, materiais, atrás das quais segue todo o resto. Walter Benjamin lembra que "a luta de classes é uma luta pelas coisas brutas e materiais, sem as quais não existem as refinadas e espirituais. Mas na luta de classes essas coisas espirituais não podem ser representadas como despojos atribuidos ao vencedor. Elas se manifestam nessa luta sob a forma da confiança, da coragem, do humor, da astúcia, da firmeza, $e$ agem de longe, do fundo dos tempos. Elas questionarão sempre cada vitória dos dominadores" $" 30 \mathrm{E}$, não raro, nas atitudes mais comezinhas encontramos as marcas dos vencidos, vencedores, nos costumes e na esperança.

É mister não esquecer, por exemplo, a Revolução Cabana desencadeada em Belém do Pará, no primeiro reinado, em 1835; a Revolução Praieira de 1848, no Recife, durante o segundo reinado; a Guerra de Canudos no sertão baiano, em 1896, no nascer da República; e, hoje, o Movimento dos Sem-Terra, protagonistas atuais da permanente guerra no campo.

A Revolução Cabana de 1835 pretendia fazer da independência recémadquirida um movimento de afirmação do povo brasileiro. A doutrina básica dos cabanos era a independência política externa e a emancipação social interna, decorrentes da consciência de ser cidadãos, rejeitando ser súditos permanentes de colonizadores eternos. ${ }^{31}$ Em oposição à cidadania parcial, do Estado brasileiro, nascido pela independência, que tipificava os filhos da terra como 'selvagens' objeto de 'pacificação', a base dominada lutava pela cidadania plena e socializada. Lutavam os brasileiros nativos por uma cidadania indivisivel e plena para todos, socializando assim os direitos e os deveres. ${ }^{32}$

30. Walter Benjamin. Obras escolhidas: magia e técnica, arte e politica. Editora Brasilicnsc, São Paulo, 1985, p. 224.

31. Pasqualc di Paolo. Cabanagem - a revolução popular da Amazônia, Ediçõcs Ccjup, Bclém, 1990, p. 369.

32. cf. idem, p. 373. 
A Revolução Praieira de 1848 desfilava vários interesses: mudança de hegemonia política, ideal republicano, insatisfação popular. Reivindicava mudanças institucionais com a convocação de uma Assembléia Constituinte para uma reforma liberal. Era a revolução para "conquistar e construir uma pátria" Voto universal, direito ao trabalho, proteção ao comércio interno, independência dos poderes eram algumas das reivindicações mais radicais do movimento, angariando com facilidade a força dos homens livres e desapossados. "Mais do que um movimento político era assim um movimento popular. A praia era a maioria, era quase o povo pernambucano todo" 33

Severamente reprimida, sob o lema 'poupar os submissos e debelar os soberbos', as autoridades, após a repressão armada, adotavam uma campanha de desmoralização do movimento e de seus líderes, prática que se tornou constante na vida pública brasileira.

O episódio de Canudos, dos mais violentos embates contra civis no Brasil, mostra um misto de fervor religioso e obstinação daqueles cujo único patrimônio era a própria vida. Numa região assolada pela seca, os sertanejos unem-se à figura messiânica e nostálgica de Antônio Conselheiro, que lhes dava esperança de dias melhores pela religiosidade e pela volta da monarquia. Em torno destes ideais, fundaram um povoado que atingiu 5 mil moradias. Tomando ciência destas habitações, o Governo central manda tropas da República para dissolvê-las. Na sua marcha pelo sertão, a tropa assustava àqueles que viviam sua vida e de quem o Estado nunca se lembrou, que partiam fugidos de suas casas, levando a notícia a Canudos de que este povoado era o alvo dos militares em marcha. A multidão organizou-se com seus utensílios de trabalho, atacaram na surpresa a primeira tropa. Quatro tropas serão necessárias para acabar com o vilarejo de Canudos e toda sua população. Não houve prisões, não houve processo, e ao final mal se sabiam as razões do ataque.

De comum nestes episódios está o distanciamento do Estado - seus atos e políticas - da maior parte da população. A formação do povo por segmentos estamentais e a incompreensão da diversidade brasileira nega sistematicamente a solidariedade e a cooperação - verdadeiras amarras da sociedade. Somos um povo assentado em grande território, bastante diverso pela construção cultural, unidos pela língua e - talvez - por um certo ufanismo epicurista por nossas riquezas sensuais (nossa geografia incomparável, nossas praias as mais belas, nossa comida - a mais saborosa, nossas músicas as melhores).

Encerrar este lampejo dos passos do Estado e da Nação brasileira requer a voz daqueles que, com genialidade, expressam o amor ao país e ao povo que o constitui. Precisamos tornar nossa sociedade responsável pelas crianças e anciãos, apregoa Darcy Ribeiro. E "isso só se alcançará através da garantia de pleno emprego, que supõe uma reestruturação agrária, porque ali é onde mais se pode multiplicar as 
oportunidades de trabalho produtivo" 34 É, sem dúvida, na diversidade das regiões que estão as raizes de nossa riqueza cultural, repisa Celso Furtado. Mas a preservação dessa riqueza exige que o desenvolvimento material se difunda por todo o território nacional $^{35} \quad$ A solidariedade é mais rica no diverso, onde a cooperação se materializa na construção do outro e não na reprodução do mesmo. O poder da originalidade e da criatividade aflora em todos os momentos da história em que o povo brasileiro se reconhece como unidade, no fado de um destino comum, isto é, como Nação.

São Paulo, março de 2002.

34. Darcy Ribciro. opus cit., p. 200.

35. Cclso Furtado. "Nova Conccpçào do Libcralismo", in O Longo Amanhecer: reflexões sobre a formação do Brasil. Paz c Terra, Rio de Janciro, 1999 , p. 46-7. 